\title{
DEVELOPMENT OF TOEFL APPS IN THE LANGUAGE LABORATORY OF MA'ARIF ISLAMIC INSTITUTE (IAIM) NU METRO -LAMPUNG
}

\author{
Rizky Hidayatullah ${ }^{1 *}$, Choirudin ${ }^{2}$, Andika Ari Saputra ${ }^{3}$, Dian Risky Amalia ${ }^{4}$, Faisal Rahman 5 \\ 1,2,3,4 Institut Agama Islam Ma'arif NU Metro \\ ${ }^{5}$ University of Sari Mulia Banjarmasin \\ rizkyiaimnu@gmail.com
}

\begin{abstract}
The aims of the research develops TOEFL apps to change the offline to online system because pandemic era, the online system is not only in TOEFL Test but also in the service of language laboratory of IAIMNU Metro that change from offline system to online system. The Changing the offline system to an online system is certainly not an easy thing for language laboratory officers, because from the registration system to the test system must be held in online form. the use of technological advances needs to be carried out by language laboratory officers from registration, participant data collection, tutorial scheduling, tutorial systems and TOEFL test. In this study, the authors consider the affective domain phenomenon in language learning. The author uses a qualitative approach to investigate and analyze the results of student interviews which are the influence of two languages on student performance at the Islamic Institute of Islamic Studies Ma'arif NU Metro. In qualitative research, discussion about participation and research location. The research methodology used by the researcher is descriptive qualitative research because this research requires development of English material. the development model can be developed on three models: procedural, conceptual, and theoretical. The result of this research is the result of this research is the convenience for test participants and also the TOEFL tutorial at IAIMNU Metro, marked with students can feel fast and also the design of the apps is quite easy to understand.
\end{abstract}

Keyword: Development System, Language Laboratory, Pandemic Era, TOEFL Apps.

\section{INTRODUCTION}

Language is a form of communication, both oral and written. Language is also divided into formal and informal languages, which require different places for this reason. Language is very important for life because human being needs language in conversing or communicating (R Development Core Team, 2011). Now in Indonesia, there are many schools or campuses that implement development of language, there are some school develop the language test for the student and also all campus in Indonesia require TOEFL as system language Improvement (Wait \& Gressel, 2009).

TOEFL stands for Test of English as a Foreign Language.. This test is for undergraduate (S-1) and graduate (S-2 or S-3) programs. In 1964, ETS (Educational 
Testing Center) in New Jersey, United States created the TOEFL (Service, 2011). Its purpose is as a tool that filters out students by English. At this time TOEFL is very developed in Indonesia on campuses required to have a language laboratory in language development, for public campuses it is usually only English language development but on Islamic-based campuses Arabic development is also held (Chapelle et al., 2011).

Language development needs concepts that need to be fulfilled, among others: (a) the ability of students in English and Arabic as well as substance in the course must be fulfilled, (b) campuses must be able to create an environment that can support habituation in the use of language, which is not only spoken of course, but it needs written language as well (c) lectures need to emphasize problem solving exercises and and encourage students to work together to solve a problem theme with the habit of using English(Hasenstab et al., 2005).

The language laboratory is a tool for training studeents to listen and speak in foreign languages by singing the learning material that has been provided previously(Scott-Phillips \& Kirby, 2010). By playing recordings containing students' learning to answer questions or repeat sentences or pronounced words. The record of answers can be deleted to repeat lessons that have not been mastered, until they are completely known. thus, students can immediately correct the mistakes made (Linshiz et al., 2013).

The Purpose of Using the Language Laboratory in Language Teaching in accordance with the objectives and utilization of language laboratories can be used for the benefit of language teaching, namely:

a. Train skills in speaking and communicating according to the desired language.

b. Deepening the language with a wider scope with a specific purpose Improve student pronunciation

Based on the objectives of the language lab above, it can be concluded that the laboratory is used to support the fluency of language teaching and learning activities(Kirby et al., 2014).

Benefits and Functions of Language Laboratory in Language Teaching The purpose of teaching Indonesian cannot be separated from carrying out the guidance and development of the Indonesian language. Coaching \& development can be seen from two aspects, namely the status dimension and the corpus dimension. The language laboratory is available in various supporting learning media and as a tool to achieve the goals of language teaching(Chen et al., 2016).

The benefits and advantages of using a language laboratory in language teaching require full concentration, including:

a. Providing valuable experiences in a more concrete form, for example experiences in controlling conditions, changing relationships, interpreting data, and drawing conclusions.

b. Inviting students to actively participate because it emphasizes direct experience, providing a multisensory experience, including one step experience, which is learning motor skills in an academic environment. 
Thus, this method can combine various teaching styles May develop habit, accuracy, and tolerance for ambiquities(Vanderplank, 2010).

In the concept of education needed in Indonesia, this level of ability is supported to be mastered. Dominated as bilingual, namely teachers at the level of mastering only one language. Where it has not been approved, it is appropriate to become a tutor or teacher on language improvement. Lecturers who are specialized in language, can be questioned in English, English courses, and the dominant English language is Indonesian(Hidayatullah et al., n.d.: 2019). Questions about teaching English they will use the language which is more dominant. Get introductory assistance with a high level of English that can be applied when teaching semesters. The results showed that language acquisition in general, the level of a person's ability to language can be confirmed because it has been improved or has been used since childhood(Amankulova \& Seisembieva, 2011).

After the emergence of the Covid-19 outbreak in the world, the education system began looking for an innovation in the teaching and learning process. Moreover, the Circular no. 4 of 2020 from the Minister of Education and culture which recommends that all activities in educational institutions must keep their distance and all material delivery will be delivered in their respective homes (Tim COVID-19 IDAI, 2020). Every institution is also required to provide the latest innovations to shape this highly effective learning process. Unfortunately, not all educational institutions seem to fully understand the latest innovations that must be used to carry out learning during a pandemic. Most of them are still unable to adjust it because of constraints on facilities and infrastructure(Daniel, 2020).

Based on the above regulations, of course the IAIMNU Metro language laboratory must have an online system in its operations including the provision of materials and also the TOEFL tests. but the need for extraordinary readiness considering the whole system must be changed in the online system. habituation also needs to be paid attention to for students and tutors.

Changing the offline system to an online system is certainly not an easy thing for language laboratory officers, because from the registration system to the test system must be held in online form. the use of technological advances needs to be carried out by language laboratory officers from registration, participant data collection, tutorial scheduling, tutorial systems and TOEFL tests (Rahman \& Hidayatullah, 2019).

\section{METHODS}

The types of research carried out in this study are descriptive. Descriptive research is generally carried out with the main objective, that is to describe systematically the facts and characteristics of the object or subject researched precisely. In recent developments, research methods . Description Alternative: Many researchers also do descriptive because of two reasons. First, from empirical observations indicate that most of the research reports were carried out in descriptive form. Second, descriptive methods are very useful for get a variety of problems related to the field of education and human behavior.

For this reason, on this occasion the researchers obtained the data to the maximum extent possible more in-depth observation and analysis was required. These activities were 
pursued through a qualitative approach, because of the procedure. This research would describe or describe in general about "Development Of Toefl Apps In The Language Laboratory Of Ma'arif Islamic Institute (Iaim) Nu Metro -Lampung" (Hplc, 2014).

In this study, the authors consider the affective domain phenomenon in language learning. The author used a qualitative approach to investigate and analyze the results of student interviews which are the influence of two languages on student performance at the Islamic Institute of Islamic Studies Ma'arif NU Metro. In qualitative research, discussion about participation and research location(Elo \& Kyngäs, 2008).

The research methodology used by the researcher was descriptive qualitative research because this research requires development of English material. the development model had to be developed on three models: procedural, conceptual, and theoretical (Creswell, 2013).

\section{Research Approach}

The research approach used in this research is a qualitative approach. As for what is meant by qualitative research, namely research that intends to understand the phenomena of what the research subject is experiencing in a holistic manner, and by means of descriptions in the form of words and language, in a special natural context and by utilizing various scientific methods. The type of research approach is descriptive. Descriptive research is research that seeks to address existing problem solutions based on data(Tracy, 2010).

\section{Data Resource}

Data are raw materials that need to be processed to produce information, both qualitative and quantitative data that show facts. On the other hand, data is material information about the object of learning something. Data can be found by observation, interviews, documentation, and so on, data from analyzing supporting factors for Development of Language Laboratory Service On Online System(Flyvbjerg, 2006).

3. Object Reserch

The object of research in this study were several sample stageholders at IAIMNU Ma'arif Metro Lampung and Students.

\section{Data Analysis Techniques}

Data analysis or data processing is a more detailed and in-depth form of analysis that also discusses a theme or subject matter. Where in this analysis, the focus of research and discussion, although directed at certain fields or aspects, is the discrepancy of phenomena which is the central theme of the research problem(Hinrichs et al., 2017).

\section{RESULTS}

There are three (three points used as the key goals in this report, namely:

1) making TOFL Apps for online TOEFL Tutorials

2) determining the level of student satisfaction with the use of TOEFLApps

3) to determine the increase in student TOEFL test results after using TOEFL Apps. 
Make TOEFL Software to enhance and get around the pandemic IAIMNU Metro Language Lab facilities so that TOEFL learning activities can continue to operate. Online TOEFL Test I, Online Test II, Online Test III, all of the content listed is included in the TOEFL Apps that we call EL-Lab that students can download to support their TOEFL scores and make it easier for TOEFL to learn and enhance the results of the TOEFL Test.

In order to be easier to open on Android or Student Ios cell phones and of course, student laptops, the questions found in the EL-Lab application are connected to Google Form. An example of a product image in the form of a TOEFL app and the following description is given below:

Picture 1 : Display applications on android
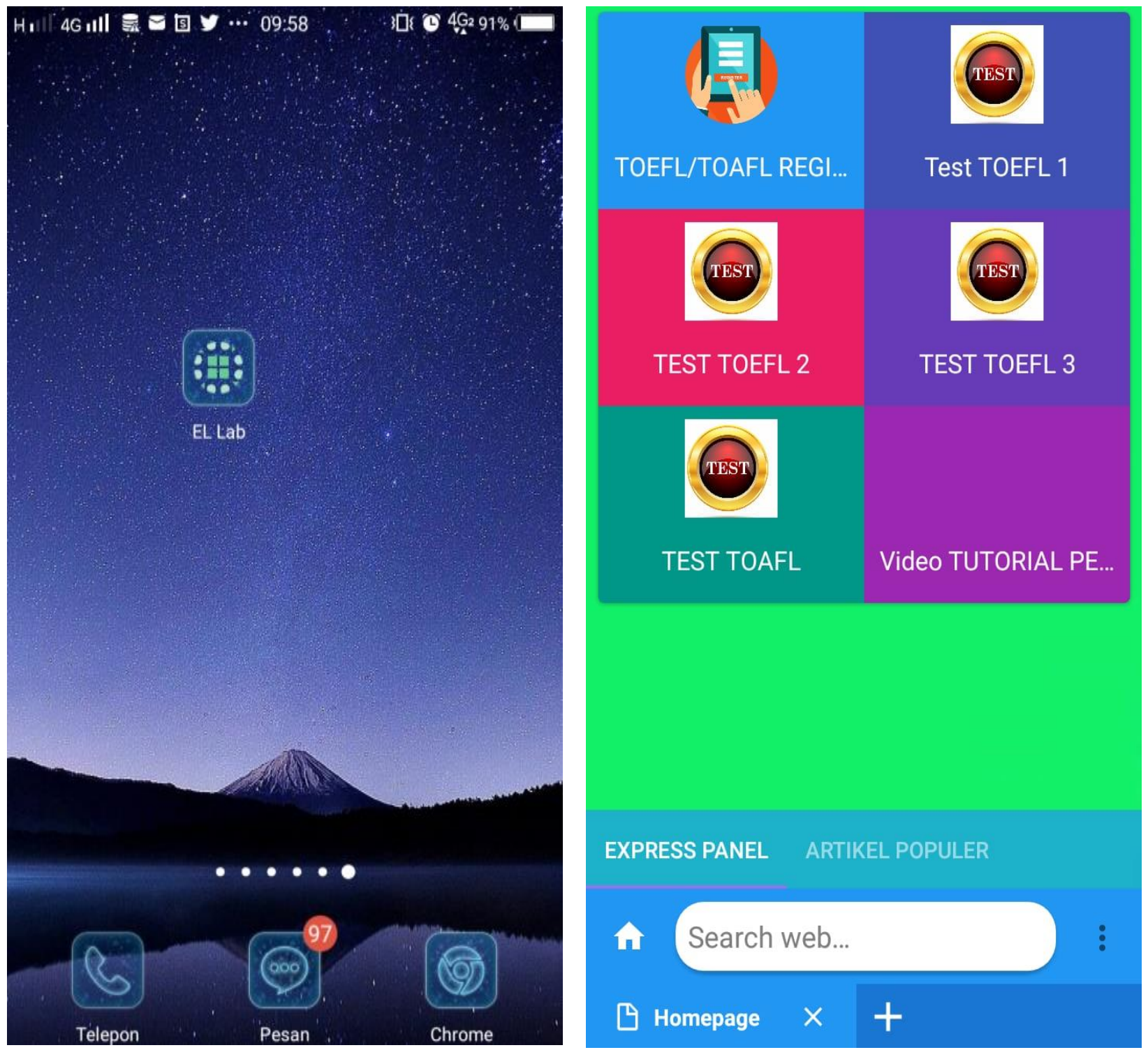
Picture 2: Display when the registration menu is opened

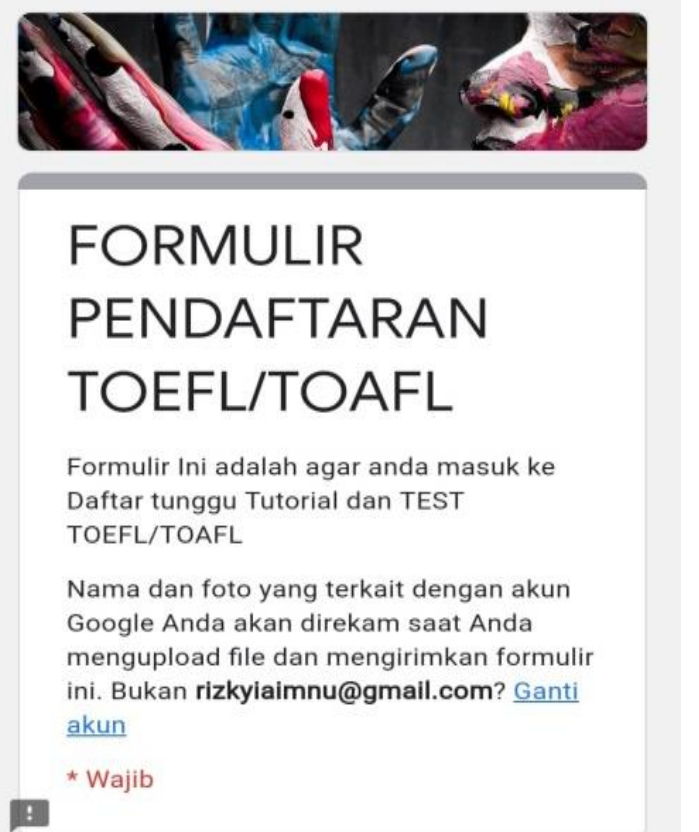

Picture 3 : Display when the TOEFL test menu is opened and need to complete Registration

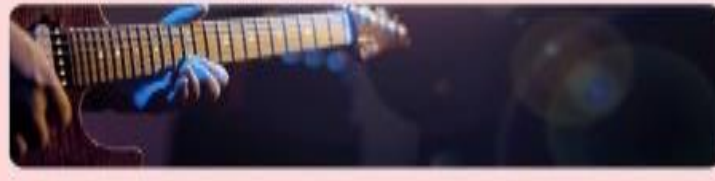

Alamat email *

Email Anda

\section{TOEFL TEST}

Isi Data Lengkap Anda dengan benar

Nama dan foto yang terkait dengan akun Google Anda akan direkam saat Anda mengupload file dan mengirimkan formulir ini. Bukan rizkyiaimnu@gmail.com? Ganti akun

* Wajib

NPM *

Jawaban Anda

Alamat email *

Nama Lengkap *

Jawaban Anda

Program Studi * 
Picture 4 : TOEFL Listening, Structure, and Reading Test Display

\section{LISTENING ONLINE}

Time Approximately 35 Minutes

(Including the reading of the directions for each part)

In this section of the test, you will have on opportunity to demonstrate your ability to understand conversations and talks in English. There are three parts to this section. Answer all the questions on the basis of what is stated or implied by the speakers you hear. Do not take notes or write in your test book at any tame. Do not turn the pages until you are told to do so.

\section{PART A}

Directions

In PART A you will hear short conversations between two poeple. After each conversation, you will hear a question about the conversation. The conversations and questions will not be repeated. After you hear a question, read the four possible answers in your test book and choose the best answer. Then, on your answer sheet, find the number of the question and fill in the space of the question and fill in the space

I. that corresponds to the letter of the answer you have chosen.

\section{STRUCTURE ONLINE}

STRUCTURE AND WRITTEN EXPESSION

Time-25 minutes (including the reading of the directions)

This section is designed to measure your ability to recognize languange that is approariate for standard written English. There are two types of questions in this section, with spesial directions for each type.

\section{STRUCURE}

\section{Directions :}

Questions 1-15 are incomplete setences. Beneath each setence you will see four word or phrases, marked (A), (B), (C), and (D). Choose the one word or phrase that best completes the setence. Then, on your answer sheet, find the number of the question and fill in the space that corresponds to the letter of the answer you have chosen. Fill in the space to that the letter inside the oval cannot be seen.

\section{READING ONLINE}

READING COMPREHENSION

Time : 55 minutes

(including the reading of the directions)

This section is designed to measure your ability to read and understand short passages similar in topic and style tho those that stutendt are likely to encounter in North American universities and colleges. This section contains reading passages and questions about the passage.

\section{READING}

Directions :

in this section you will read several passages. Each one is followed by a number of questions about it. You are to choose the one best answer. (A), (B), (C), and (D), to each question. Then, on your answer sheet, find the number of the question and fill in the space that corresponds tho the letter of the answer you have chosen.

Answer all questions about the information is a passage on the basis of what is stated or

i. implied in that passage. 
Knowing the level of student satisfaction in using the TOEFL Apps In achieving the second goal, namely making an online questionnaire to determine the level of student satisfaction in using the TOEFL Apps on the TOEFL Tutorial and the TOEFL Test are as follows: 1) Creating a satisfaction questionnaire indicator of 10 indicators 2) Using the Google application form to get information from students 3) Online questionnaires are created on Google form which are filled in by students who are taking or have used TOEFL Apps (El-Lab) 4) Students can fill out the online questionnaire anywhere and anytime. 5) The results of the online questionnaire recapitulation can be directly found on the Google Form in progress and report.The following are the results of filling out the online student questionnaire with 63 respondents with the following descriptions:

Picture 5 : questionnaire

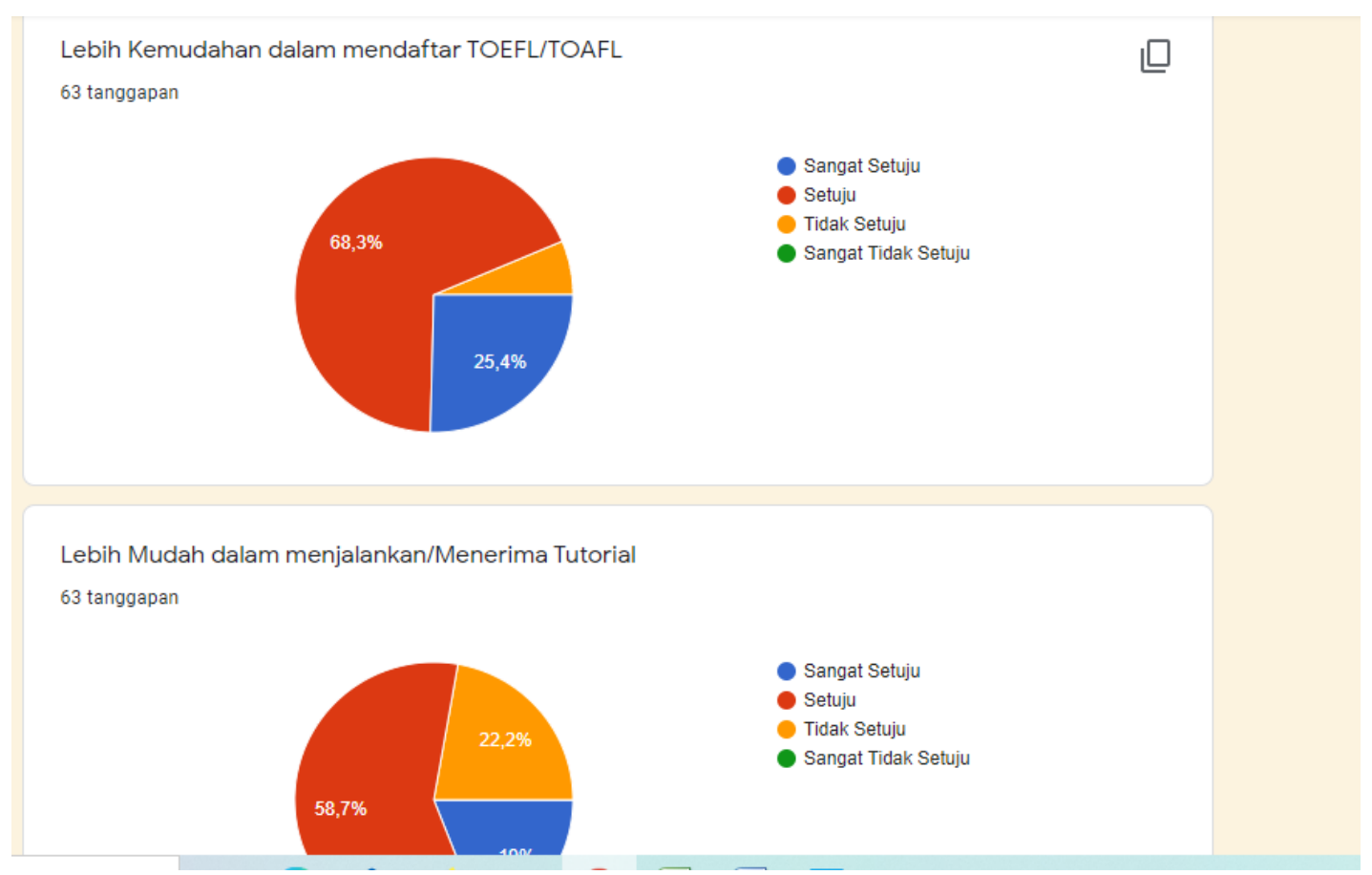

Data were obtained in the questionnaire that out of 63 students who had used TOEFL Apps reported that 68.3 percent were easier to register for TOEFL 25.4 percent reported that registering for TOEFL Apps (El-Lab) was very straightforward, only less than 5 percent said they still had trouble registering via El-Lab. 58.7 percent said it was easy to run El-Lab Apps while running the application, and 10 percent found it easy to run El-Lab apps. Just 22.2 percent said they were still having trouble running El-Lab Software. The TOEFL (El-Lab) application is very relevant for the results of the questionnaire to be developed and used in learning during the current pandemic.

Knowing the success rate of student learning outcomes in online TOEFL / Apps In order to achieve the third goal, namely to perform online tests to assess the success rate of student learning outcomes in the use of online TOEFL Apps tutorials: 1) Make TOEFL Trial 
Test Questions 2) Using the goggle form connect right with TOEFL Apps (El-Lab). 3) After knowing the results of the first test, then continue with the second test. 4) Wherever and anywhere, students can do this online. 5) The results of the recapitulation of the online post test to see a substantial improvement in the results of using TOEFL Online / Apps. 6) Then each student will compare the results of the first test, second test and third test of TOEFL. The results of the online test items are shown as follows:

Table 1: TOEFL 1 test results (Trial Test)

\section{LABORATORIUM BAHASA}

\section{INSTITUT AGAMA ISLAM MA'AARIF NU METRO HASIL TEST TOEFL I Tanggal: 13-12-2020}

\begin{tabular}{|c|c|c|c|c|c|}
\hline NO. & Keterangan & Nama Lengkap & NPM & PRODI & Score \\
\hline 1 & Tidak Lulus & Kartika & 171130097 & PBS & 380 \\
\hline 2 & Tidak Lulus & RICKY MEI BUDIARNO & 171120048 & PBS & 373 \\
\hline 3 & Tidak Lulus & Yoga adi pratama & 171130094 & PBS & 333 \\
\hline 4 & Tidak Lulus & Dwi Nur Mey Linda & 171120013 & PBS & 393 \\
\hline 5 & Tidak Lulus & Fatimatuz zahra & 183130107 & PBS & 333 \\
\hline 6 & Tidak Lulus & Siti uswatun khasanah & 181250031 & PMTK & 383 \\
\hline 7 & Tidak Lulus & Hidayatul wahidah & 181250013 & PMTK & 355 \\
\hline 8 & LULUS & Ican & 181110060 & AHS & 400 \\
\hline 9 & Tidak Lulus & Hanin pujiasih & 181250012 & PMTK & 373 \\
\hline 10 & Tidak Lulus & Yessy Anytha Dahlia & 183130108 & PBS & 355 \\
\hline 11 & Tidak Lulus & INTAN ERVIANA & 181110019 & AHS & 373 \\
\hline 12 & Tidak Lulus & Selvia Tartini M. & 171310019 & PIAUD & 375 \\
\hline 13 & LULUS & Deca amelia & 181250009 & PMTK & 415 \\
\hline 14 & Tidak Lulus & Laily Rifki Ayu Wandari & 181250017 & PMTK & 375 \\
\hline 15 & Tidak Lulus & Khoirun Nisa & 181250015 & PMTK & 355 \\
\hline 16 & Tidak Lulus & Nadia Istiqomah & 181250024 & PMTK & 345 \\
\hline 17 & Tidak Lulus & Rizki prasanti & 171120050 & PBS & 393 \\
\hline 18 & Tidak Lulus & Tri Nur Aini & 181250036 & PMTK & 333 \\
\hline
\end{tabular}

On the results of the TOEFL 1 test on December 13, 2020, it shows that only 2 people reached a value of 400 or more. 
Table 2 : TOEFL Test II result

LABORATORIUM BAHASA

INSTITUT AGAMA ISLAM MA'AARIF NU METRO HASIL TEST TOEFL II Tanggal: 14-12-2020

\begin{tabular}{cclccc}
\hline NO. & Keterangan & \multicolumn{1}{c}{ Nama Lengkap } & NPM & PRODI & Score \\
\hline 1 & LULUS & Kartika & 171130097 & PBS & $\mathbf{4 0 3}$ \\
2 & LULUS & RICKY MEI BUDIARNO & 171120048 & PBS & $\mathbf{3 6 3}$ \\
3 & Tidak Lulus & Yoga adi pratama & 171130094 & PBS & $\mathbf{3 7 3}$ \\
4 & Tidak Lulus & Dwi Nur Mey Linda & 171120013 & PBS & $\mathbf{3 3 3}$ \\
5 & Tidak Lulus & Fatimatuz zahra & 183130107 & PBS & $\mathbf{3 5 2}$ \\
6 & Tidak Lulus & Siti uswatun khasanah & 181250031 & PMTK & $\mathbf{3 5 0}$ \\
7 & LULUS & Hidayatul wahidah & 181250013 & PMTK & $\mathbf{4 5 0}$ \\
8 & LULUS & Ican & 181110060 & AHS & $\mathbf{4 0 0}$ \\
9 & Tidak Lulus & Hanin pujiasih & 181250012 & PMTK & $\mathbf{3 7 3}$ \\
10 & LULUS & Yessy Anytha Dahlia & 183130108 & PBS & $\mathbf{4 0 0}$ \\
11 & Tidak Lulus & INTAN ERVIANA & 181110019 & AHS & $\mathbf{3 9 3}$ \\
12 & LULUS & Selvia Tartini M. & 171310019 & PIAUD & $\mathbf{4 0 0}$ \\
13 & LULUS & Deca amelia & 181250009 & PMTK & $\mathbf{4 1 5}$ \\
14 & Tidak Lulus & Laily Rifki Ayu Wandari & 181250017 & PMTK & $\mathbf{3 8 3}$ \\
15 & LULUS & Khoirun Nisa & 181250015 & PMTK & $\mathbf{4 0 3}$ \\
16 & LULUS & Nadia Istiqomah & 181250024 & PMTK & $\mathbf{4 7 0}$ \\
17 & LULUS & Rizki prasanti & 171120050 & PBS & $\mathbf{4 2 0}$ \\
18 & Tidak Lulus & Tri Nur Aini & 181250036 & PMTK & $\mathbf{4 0 0}$ \\
\hline & & & & \\
\hline
\end{tabular}

The second TOEFL test results on December 14, 2020 showed significant results, namely 9 people who can score 400 or more, which indicates the effectiveness of TOEFL Apps (El-Lab) 
Table 3 : TOEFL III Test Results

LABORATORIUM BAHASA INSTITUT AGAMA ISLAM MA'AARIF NU METRO HASIL TEST TOEFL III Tanggal: 16-12-2020

\begin{tabular}{cclccc}
\hline NO. & Keterangan & \multicolumn{1}{c}{ Nama Lengkap } & NPM & PRODI & Score \\
\hline 1 & LULUS & Kartika & 171130097 & PBS & $\mathbf{4 0 3}$ \\
2 & LULUS & RICKY MEI BUDIARNO & 171120048 & PBS & $\mathbf{4 0 3}$ \\
3 & LULUS & Yoga adi pratama & 171130094 & PBS & $\mathbf{4 0 0}$ \\
4 & LULUS & Dwi Nur Mey Linda & 171120013 & PBS & $\mathbf{4 2 0}$ \\
5 & Tidak Lulus & Fatimatuz zahra & 183130107 & PBS & $\mathbf{3 7 5}$ \\
6 & LULUS & Siti uswatun khasanah & 181250031 & PMTK & $\mathbf{4 0 0}$ \\
7 & LULUS & Hidayatul wahidah & 181250013 & PMTK & $\mathbf{4 0 0}$ \\
8 & LULUS & Ican & 181110060 & AHS & $\mathbf{4 2 5}$ \\
9 & LULUS & Hanin pujiasih & 181250012 & PMTK & $\mathbf{4 7 3}$ \\
10 & LULUS & Yessy Anytha Dahlia & 183130108 & PBS & $\mathbf{4 5 5}$ \\
11 & LULUS & INTAN ERVIANA & 181110019 & AHS & $\mathbf{4 1 6}$ \\
12 & LULUS & Selvia Tartini M. & 171310019 & PIAUD & $\mathbf{4 0 0}$ \\
13 & LULUS & Deca amelia & 181250009 & PMTK & $\mathbf{4 1 5}$ \\
14 & Tidak Lulus & Laily Rifki Ayu Wandari & 181250017 & PMTK & $\mathbf{3 7 5}$ \\
15 & Tidak Lulus & Khoirun Nisa & 181250015 & PMTK & $\mathbf{3 5 5}$ \\
16 & LULUS & Nadia Istiqomah & 181250024 & PMTK & $\mathbf{4 0 0}$ \\
17 & LULUS & Rizki prasanti & 171120050 & PBS & $\mathbf{4 5 5}$ \\
18 & LULUS & Tri Nur Aini & 181250036 & PMTK & $\mathbf{4 2 0}$ \\
\hline
\end{tabular}

From the results of the third TOEFL test which was held on December 16, it was shown that the increase in student TOEFL scores increased with more students achieving a score of 400 or more, which indicates that the score when students actively access TOEFL Apps or EL-Lab accustomed to TOEFL questions and the activeness of students in following TOEFL tutorials are also an influence in improving the TOEFL test results.

\section{DISCUSSION}

There are reasons related to the key goals from the three findings above, namely: 1) making TOEFL Apps for TOEFL Tutorials online 2) determining the degree of student satisfaction in using TOEFL Apps 3) determining the increase in student TOEFL test results after using TOEFL Apps. 
Bringing positive results, namely the TOEFL apps, can be a student solution during a pandemic to learn TOEFL and can be easily opened anytime and anywhere since it supports Android, iOS or Student Laptops and the size of apps that are not so big can make it possible to develop TOEFL Apps (El-Lab) into other lecture materials, of course development needs to be done to make TOEFL Apps the most up-to-date application and can be accessed by anyone, even high school or junior high school students.

The level of student satisfaction indicates good results because many agree that TOEFL online is the correct application to use in a pandemic era and a simple application as well. A student named Nurfadhilah said from interviews with students using TOEFL Apps (El-Lab) that this application is very good and easy to run in the future, so it can be used in other learning so that all subjects can be easily accessed."

By using the TOEFL Apps (El-Lab) from Pre-test to Post-Test scores, test results have increased by starting with online tutorials taught by many English lecturers using the El-Lab application that is connected to the Google Meeting to make it easy for the participants to access.

However when accessing TOEFL Apps (El-Lab), there are many obstacles for TOEFL students, namely:

1. Signal issues that often render the software incapable of running smoothly.

2. Student test results are often not reported / submitted so that the results of the test are not received.

3. Some students also do not have an optimal understanding of the use of Software, which appears to be used when the TOEFL exam alone is not a prerequisite to learn TOEFL.

4. It is really important to upgrade the TOEFL applications because it is not as appealing as the Google Play developer application and the content of the application also needs to be re-developed.

\section{CONCLUSION}

TOEFL Apps is an online TOEFL development solution designed to make it easier for students to register, follow tutorials and online TOEFL tests, especially in this pandemic, since it does not enable students to leave the house and so on with the design of apps that are easy to understand and operate, TOEFL Apps (El-Lab) is an online TOEFL test solution for students as well as the design of apps that are easy to understand and operate, he TOEFL Apps (El-Lab) is a solution for students for the online TOEFL test as well as a language laboratory in organizing registration, tutorials and online tests.

The results of the questionnaire indicate that learners are satisfied with the TOEFL Apps given by the Language Laboratory by demonstrating that learners are satisfied with the TOEFL Apps (El-Lab).With the existence of the TOEFL Online (El-Lab), the test results have dramatically increased, including the Test I, the tutorial followed by the second TOEFL test, and even the Third test, which indicates that the student test results continue to increase. 


\section{ACKNOWLEDGMENT}

This research takes the title " DEVELOPMENT OF TOEFL APPS (EL-LAB) DURING PANDEMIC ERA IN THE LANGUAGE LABORATORY OF MA'ARIF ISLAMIC INSTITUTE (IAIM) NU METRO -LAMPUNG" which is one of the obligations of educators in carrying out the Tri Dharma of Higher Education, namely research under the auspices of the Research, Development and Community Service Institute. (LP3M) Agma Islam Institute Ma'arif NU (IAIMNU) Metro Lampung. For the completion of this service program, the service provider would like to thank all parties involved:

1. Dr. Mispani, M.Pd.I., as the Chancellor of the Islamic Institute of Religion Ma'arif NU (IAIMNU) Metro Lampung.

2. Habib Sulton A. SH, S.H.I., M.H., as chairman of the Institute for Research, Development and Community Service (LP2M) Agma Islam Ma'arif NU Institute (IAIMNU) Metro Lampung.

3. Mrs. Dian Risky A., M.Pd.I as the Chairman of Language Laboratory IAIMNU metro.

4. The research subjects of The students IAIMNU Metro who have followed this program well, hopefully the knowledge gained is beneficial for the advancement of education at IAIMNU metro

5. All those who have helped a lot in this research. Researchers realize that this dedication is still far from perfect. For this reason, criticism and suggestions that are very constructive in nature, researchers can develop science in the future.

\section{REFERENCES}

Amankulova, Z. I., \& Seisembieva, S. K. (2011). Teaching English as a foreign language. Analele Universitatii Din Craiova, Seria Filozofie. https://doi.org/10.2307/811234

Chapelle, C. A., Enright, M. K., \& Jamieson, J. M. (2011). Building a validity argument for the test of english as a foreign language ${ }^{\mathrm{TM}}$. In Building a Validity Argument for the Test of English as a Foreign Language. https://doi.org/10.4324/9780203937891

Chen, D. L., Schonger, M., \& Wickens, C. (2016). oTree-An open-source platform for laboratory, online, and field experiments. Journal of Behavioral and Experimental Finance. https://doi.org/10.1016/j.jbef.2015.12.001

Creswell, J. (2013). Qualitative, quantitative, and mixed methods approaches. In Research design.

Daniel, S. J. (2020). Education and the COVID-19 pandemic. Prospects. https://doi.org/10.1007/s11125-020-09464-3

Elo, S., \& Kyngäs, H. (2008). The qualitative content analysis process. Journal of Advanced Nursing. https://doi.org/10.1111/j.1365-2648.2007.04569.x

Flyvbjerg, B. (2006). Five misunderstandings about case-study research. Qualitative Inquiry. https://doi.org/10.1177/1077800405284363 
Hasenstab, S., Wetmore, R. F., \& Eggleston, T. (2005). Language development. In Complications in Pediatric https://doi.org/10.7810/9780908912964_8

Otolaryngology.

Hidayatullah, R., Saputra, A. A., Amalia, D. R., \& Hasyim, A. A. (n.d.). Schema Activation Strategy in Reading Comprehension.

Hinrichs, U., Carpendale, S., Knudsen, S., \& Thudt, A. (2017). Analyzing qualitative data. Proceedings of the 2017 ACM International Conference on Interactive Surfaces and Spaces, ISS 2017. https://doi.org/10.1145/3132272.3135087

Hplc, Q. (2014). Quantitative \& Qualitative HPLC. Www.Chromacademy.Com.

Kirby, S., Griffiths, T., \& Smith, K. (2014). Iterated learning and the evolution of language. In Current Opinion in Neurobiology. https://doi.org/10.1016/j.conb.2014.07.014

Linshiz, G., Stawski, N., Poust, S., Bi, C., Keasling, J. D., \& Hillson, N. J. (2013). PaR-PaR laboratory automation platform. ACS Synthetic Biology. https://doi.org/10.1021/sb300075t

R Development Core Team, R. (2011). R: A Language and Environment for Statistical Computing. In R Foundation for Statistical Computing. https://doi.org/10.1007/978-3540-74686-7

Rahman, F., \& Hidayatullah, R. (2019). Gamification of EFL classroom in a healthcare education context in Indonesia: Kahoot! June, 14-16. http://e-proceedings.iainpalangkaraya.ac.id/index.php/inacelt

Scott-Phillips, T. C., \& Kirby, S. (2010). Language evolution in the laboratory. In Trends in Cognitive Sciences. https://doi.org/10.1016/j.tics.2010.06.006

Service, E. T. (2011). Program History. TOEFL IBT Research.

Tim COVID-19 IDAI. (2020). Protokol Tatalaksana Covid-19. 1.

Tracy, S. J. (2010). Qualitative quality: Eight a"big-tent" criteria for excellent qualitative research. Qualitative Inquiry. https://doi.org/10.1177/1077800410383121

Vanderplank, R. (2010). Déj vu A decade of research on language laboratories, television and video in language learning. Language Teaching. https://doi.org/10.1017/S0261444809990267

Wait, I. W., \& Gressel, J. W. (2009). Relationship between TOEFL score and academic success for international engineering students. Journal of Engineering Education. https://doi.org/10.1002/j.2168-9830.2009.tb01035.x 